\author{
유리섬유로 보강된 수지에서 제품설계 및 성형조건에 따른 휨의 연구: \\ Part 1. 비결정성 수지 \\ 이 민 $*$ 김 혁 · 류민영**,* \\ 서울과학기술대학교 대학원, *서울과학기술대학교 (현)영남이공대학 기계자동차공학부 기계계열, \\ **서울과학기술대학교 기계시스템디자인공학과 \\ (2011년 11월 20일 접수, 2012년 3월 27일 수정, 2012년 3월 29일 채택)
}

\title{
A Study on the Warpage of Glass Fiber Reinforced Plastics for Part Design and Operation Condition: Part 1. Amorphous Plastics
}

\author{
Min Lee*, Hyeok Kim, and Min-Young Lyu**,† \\ Graduate School of NID Fusion Technology, Seoul National Univ. of Science and Technology, \\ 172 Gongneung 2-dong, Nowon-gu, Seoul 139-743, Korea \\ *Mechanical Engineering, Yeungnam College of Science \& Technology, 170 Daemyeong-dong, Nam-gu, Daegu 705-703, Korea \\ **Department of Machinery System Design Engineering, Seoul National Univ. of Science and Technology, \\ 170 Daemyeong-dong, Nam-gu, Daegu 705-703, Korea
}

(Received November 20, 2011; Resived March 27, 2012; Accepted March 29, 2012)

\begin{abstract}
초록: 사출 성형품에서 발생되는 뒤틀림은 성형공정 중 제품의 불균일한 수축과 잔류응력의 이완으로 인하여 나타 나는 현상이다. 휨이나 뒤틀림 현상을 방지하기 위해서 성형품이 강성이 있도록 설계하거나 수지에 유리섬유 등으 로 보강하여 사용한다. 본 연구에서는 플라스틱의 성형품에서 성형품의 설계에 따른 뒤틀림 현상을 성형조건 별로 알아보았다. 성형품의 설계는 리브로 보강된 두 종류와 보강 리브가 없는 시편을 사용하였다. 수지는 유리섬유로 보 강된 비결정성 수지인 $\mathrm{PC}$ 와 $\mathrm{ABS}$ 를 사용하였다. 실험결과 휨은 리브의 설계에 따라 큰 변화를 보였다. 게이트 주변, 게이트 반대쪽, 그리고 흐름방향쪽 등 측정위치에 따라서 휨은 다양하게 나타났다. 이러한 휨의 결과는 유리섬유의 배향과도 크게 관련이 있음을 컴퓨터 해석을 통해 확인할 수 있었다. 리브가 없는 단순 평판에서 휨이 가장 작게 나타났으며, 리브가 흐름방향으로 놓여있는 경우가 휨에 대한 큰 저항을 보였다. 시편에 나타난 휨은 성형조건보다 는 제품의 설계에 따라 크게 변하였다. 리브의 설계와 그에 따른 게이트의 위치 설정은 유리섬유의 배향과 직접적 인 관련이 있으므로 성형품의 휨 조절에 매우 중요함을 보여주었다.
\end{abstract}

\begin{abstract}
Warpage of injection molded product is caused by non-uniform shrinkage during shaping operation and relaxation of residual stress. Robust part design and glass fiber reinforced reins have been adopted to prevent warpage of part. Warpages for part designs have been investigated in this study according to the injection molding conditions. Part design contains flat specimen and two different rib designs in the flat part. Resins used in this study were glass fiber reinforced amorphous plastics, PC and ABS. Different rib designs showed significant differences of warpages in the parts. Various warpages have been observed in the three regions of the part, near gate region, opposite region to the gate, and flow direction region. Results of computer simulation revealed that the warpages were strongly related to glass fiber orientation. Flat specimen showed the smallest warpage and the specimen with ribs to the flow direction showed a high resistance to warpage. Warpage highly depended upon part design rather than molding condition. It was concluded that the rib design and selection of gate location in injection molding would be the most important factors for the control of warpage since those are directly related to the fiber orientation during molding.
\end{abstract}

Keywords: warpage, injection molding, part design, rib design, glass fiber reinforced PC, glass fiber reinforced ABS.

To whom correspondence should be addressed.

E-mail: mylyu@seoultech.ac.kr 


\section{서 론}

플라스틱은 일반 생활용품, IT 및 전기전자 제품, 기계, 자 동차 그리고 항공기 부품 등 여러 분야에서 다양하게 이용되 고 있다. 이러한 플라스틱 제품들은 많은 경우에 사출성형으 로 이루어지고 있다. 이는 사출성형이 복잡한 제품의 형상을 쉽게 성형할 수 있고 형상정밀도가 높을 뿐 아니라 생산성도 높기 때문이다. 사출성형 제품에서는 제품의 형상 및 성형 조 건에 따라 성형결함이 다양하게 발생하는데 이러한 제품결함 중에 휨이나 뒤틀림은 제품의 형상을 왜곡시키고 조립시의 문제점으로 작용된다. ${ }^{1,2}$ 따라서 이러한 휨이나 변형을 방지하 기 위해 강성을 갖는 형상 설계가 중요하다.

사출 성형품에 변형이 생기는 근본적인 원인은 성형수축 때문이다. 흐름방향과 흐름의 직각방향의 수축차이, 그리고 위치별 수축차이가 변형이나 휨을 일으킨다. ${ }^{3,4}$ 사출 성형품에 변형을 일으키는 또 하나의 원인은 잔류응력이다.,5 수지가 고온과 고압으로 금형에 채워지고 냉각되는 과정에서 성형품 에 잔류응력이 형성된다. 잔류응력은 시간이 지나면서 스스로 이완되면서 제품에 변형을 일으킨다. 이러한 변형을 방지하 기 위해서는 제품의 강건설계가 중요하다. 사출 성형품에서 나타나는 수축이나 휨, 뒤틀림에 대한 연구는 많이 진행되어

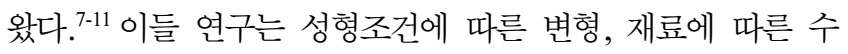
축이나 휨, 그리고 변형과 휨을 일으키는 인자의 연구가 대부 분이다. 본 연구실에서도 성형조건에 따라 단순형상의 사출성 형에서 나타나는 휨의 이방성에 대한 연구를 발표하였다. ${ }^{3,4}$ 그러나 제품의 형상에 따른 수축이나 휨에 대한 연구는 미진 하며 변형을 방지하기 위한 형상설계 역시 연구가 미진하다. 최근에 본 연구실에서 제품의 형상설계에 따른 비보강 수지 에 대한 휨의 연구결과가 있었다. ${ }^{2}$

본 연구에서는 유리섬유로 보강된 비결정성 수지에서 성형 품의 설계에 따른 휨에 대한 연구를 수행하였다. 휨은 수지 의 수축과 깊게 관련이 있으며 성형수축은 비결정성과 결정 성 수지에서 크게 다르게 나타나기 때문에 보강된 수지에서 비결정성 수지와 결정성 수지로 나눠서 연구를 수행하였다. 본 논문에서는 비결정성 수지의 연구결과를 수록하였으며, 제품의 형상설계에 따라 나타나는 휨의 경향을 파악하고자 하였다. 또한 성형조건이 휨에 얼마나 영향을 미치는지 조사 하였다. 본 연구의 결과는 사출성형품의 휨 방지를 위한 제 품설계 및 금형설계, 그리고 최적조건 설정에 응용될 수 있 다.

\section{실 험}

시편. Figure 1은 사출성형품의 형상설계에 따른 휨의 관찰 을 위한 시편을 보여주고 있다. 일반적으로 사출성형품은 변 형에 대한 강성을 부여하기 위해 다양한 리브를 설계하게 된

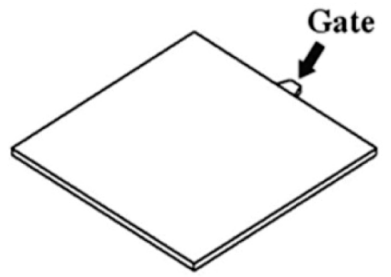

(a) Specimen 1(no ribs)

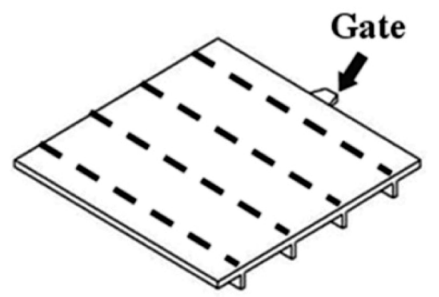

(b) Specimen 2(ribs in perpendicular to flow direction)

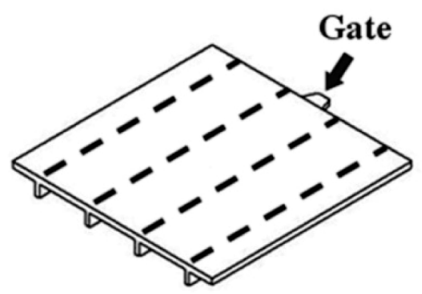

(c) Specimen 3(ribs in flow direction)

Figure 1. Specimens with ribs and without ribs.

다. 따라서 본 연구에서는 사출성형품의 리브 설계에 따른 휨 을 관찰하고자 Figure 1과 같이 시편을 고안하였다. 시편 1의 형상은 리브가 없는 정사각형의 평판으로 가로, 세로 길이가 $100 \mathrm{~mm} \times 100 \mathrm{~mm}$ 이고 두께는 $3 \mathrm{~mm}$ 이다. 시편 2와 3 은 시편 1 과 같은 형상에서 보강 리브의 설계가 수지의 흐름과 직각인 방향과 수지의 흐름방향으로 놓여 있다. 리브의 두께는 $2 \mathrm{~mm}$ 이고 높이는 $6 \mathrm{~mm}$ 이다. 시편 2 와 3 에서 리브의 수는 각각 4 개씩이며 리브간 간격은 같고, 두 시편에서 리브 방향만 다르 다.

재료, 성형조건, 성형기 및 컴퓨터 모사. 본 연구에서 사용 한 수지는 비결정성 수지에 유리섬유가 $30 \%$ 첨가된 $\mathrm{PC}$ (LUPOY GP2300, LG Chemical)수지와 역시 유리섬유 30\% 로 보강된 ABS(LUPOS GP2300, LG Chemical) 수지이다.

Table 1은 본 연구의 실험조건들을 보여 주고 있다. 수지에 따라 보압의 크기, 금형 온도, 수지 온도를 변경하여 실험을 수행하였다. 두 수지의 유변학적 물성이 다르므로 두 수지의 성형조건을 다르게 설정하였다. Figure 2에 두 수지의 전단점 도 곡선이 나타나 있다.

실험에 사용된 사출성형기는 $\mathrm{ENGEL}$ 의 $\mathrm{VC} 330 / 80$ 으로 형 체력은 80 ton이다.

실험과 같은 조건으로 컴퓨터 해석을 진행하였다. 사용한 
Table 1. Injection Molding Conditions for Glass Fiber Reinforced PC and ABS

\begin{tabular}{cccc}
\hline Resin & $\begin{array}{c}\text { Packing pressure } \\
{[\mathrm{MPa}]}\end{array}$ & $\begin{array}{c}\text { Mold } \\
\text { temperature } \\
{\left[{ }^{\circ} \mathrm{C}\right]}\end{array}$ & $\begin{array}{c}\text { Injection } \\
\text { temperature } \\
{\left[{ }^{\circ} \mathrm{C}\right]}\end{array}$ \\
\hline \multirow{2}{*}{$\mathrm{PC}$} & 48 & 105 & 275 \\
$+30 \% \mathrm{GF}$ & 96 & 115 & 285 \\
& 144 & 125 & 295 \\
\hline \multirow{2}{*}{$\mathrm{ABS}$} & 24 & 70 & 230 \\
$+30 \% \mathrm{GF}$ & 48 & 80 & 240 \\
& 72 & 90 & 250 \\
\hline
\end{tabular}

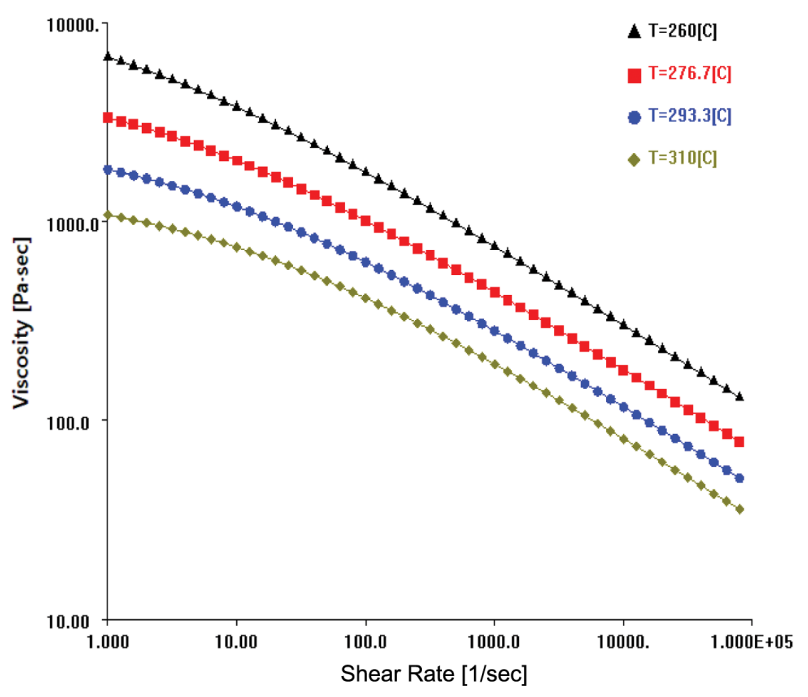

(a) Glass fiber reinforced (30\%) PC

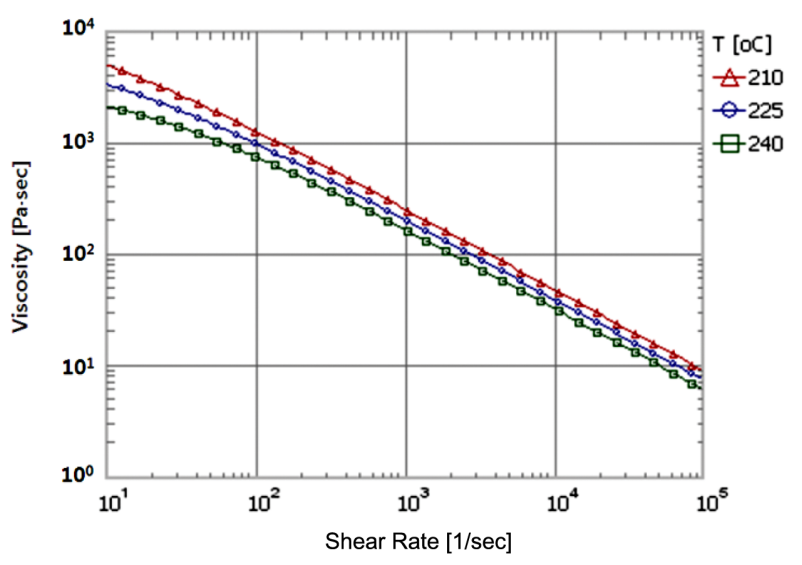

(b) Glass fiber reinforced (30\%) ABS

Figure 2. Shear viscosity curves for glass fiber reinforced PC and ABS used in this study.

프로그램은 Moldflow이며 두께방향에서 유리섬유 배향을 살 펴보기 위해 3차원 해석을 실시하였다.

휨의 측정 방법. Figure 3 은 시편에서 휨을 측정하기 위한 방법을 보여주고 있다. 3차원 레이져 측정 장비( $\mathrm{DE}$ Meet

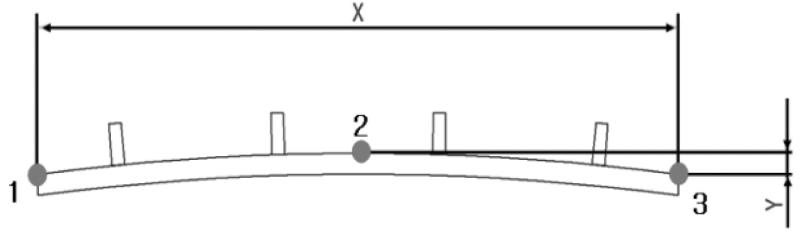

Figure 3. Measurement of warpage using three points in the specimen.

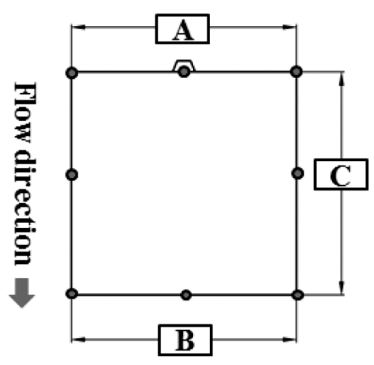

(a) Specimen 1

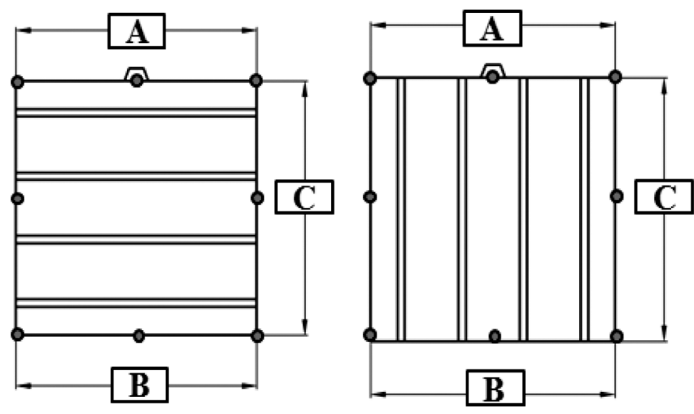

(b) Specimen 2

(c) Specimen 3

Figure 4. Measurement regions (A, B, C) of warpages in the specimens.

404, Schut Geometrical Metrology Co., Netherland)를 이용 하여 Point $1,2,3$ 의 좌표를 측정하였다. 그리고 Point 1 과 3 을 잇는 직선상에서 Point 2 의 높이 방향의 거리(Y값)를 휨 의 양으로 정의하고 이를 측정하였다.

Figure 4에 나타난 바와 같이 휨을 각 시편의 세 영역에서 측정하였다. 게이트 쪽의 변(A), 게이트와 반대쪽에 있는 변 (B), 그리고 수지가 흐르는 방향의 변(C), 즉 시편의 옆 부분 의 변이다. 휨의 측정은 사출성형 후 24 시간이 경과한 후에 수행하였다.

\section{결과 및 토론}

수지의 유동선단과 유리섬유의 배향. Figure 5 와 Figure 6 은 컴퓨터 해석을 통한 PC 수지의 유동선단과 유리섬유의 배 향을 보여주고 있다. Figure 5 에서 세 개의 시편에서 유동선 단이 다소 차이를 보이고 있으며, 유동방향에 직각으로 리브 


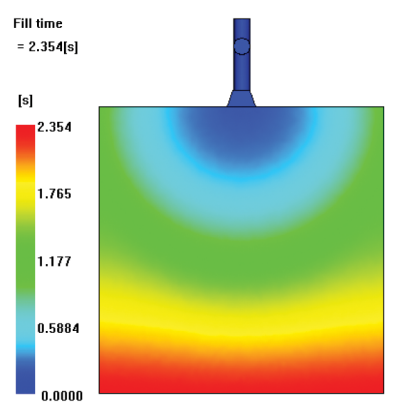

(a) Specimen 1

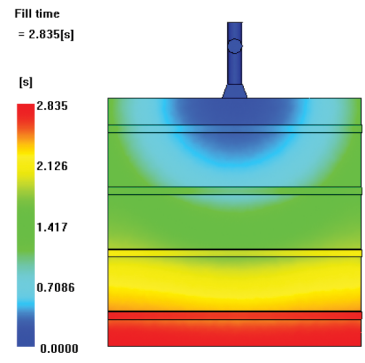

(b) Specimen 2

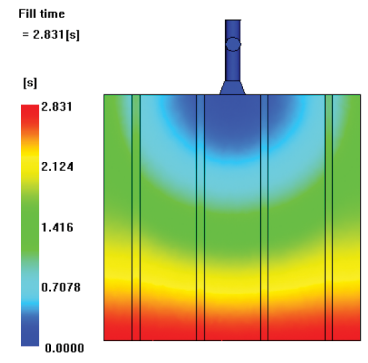

(c) Specimen 3
Figure 5. Computer simulation of flow front for glass fiber reinforced PC.

가 놓여 있는 시편 2에서 가장 균일한 유동선단을 보여주고 있다. 이는 리브가 유동방향과 직각으로 놓여 있어서 이 직각 으로 놓여 있는 리브를 채우고 유동이 앞으로 진행하기 때문 에 흐르는 방향으로 유동선단이 균일하게 나타난 것으로 보 인다. 충전시간을 보면 리브가 없는 시편 1 이 체적이 가장 작 기 때문에 가장 먼저 채워졌고 $(2.35 \mathrm{sec})$, 그 다음이 리브가 유동선단과 나란하게 놓인 시편 3 에서 채워졌고 $(2.84 \mathrm{sec})$, 리 브가 유동선단에 직각으로 놓인 시편 2에서 가장 늦은 충전 을 보였다 $(2.83 \mathrm{sec})$. 충전시간 차이가 매우 작아 크게 유효하 지는 않지만 컴퓨터 해석에서 리브의 설계에 따른 충전의 차 이가 물리적으로 합당함을 보여주고 있었다.

Figure 6은 충전에 의한 유리섬유의 배향을 보여주고 있다. 시편 1에서는 수지가 흐르는 방향, 즉 $\mathrm{C}$ 방향으로 유리섬유가 배향됨을 볼 수 있다. $\mathrm{A}$ 나 $\mathrm{B}$ 에서 본 유리섬유의 배향은 시편 의 중앙에서 바깥쪽으로 흘러가는 모양을 보였으며, B에서는 양 쪽 흐름이 끝나는 곳에서 수지가 더 이상 흘러갈 수 없기 때문에 유리섬유가 수직으로 배향됨을 볼 수 있다. 시편 2의 $\mathrm{A}$ 에서 본 유리섬유 배향을 보면 수지가 시편 중앙에서 리브 위쪽으로 흘러간 다음 좌우 양쪽으로 흘러감을 볼 수 있다. $\mathrm{B}$ 와 $\mathrm{C}$ 에서 본 유리섬유 배향은 리브 위쪽으로 일어남을 알 수 있다. 시편 3 에서는, $\mathrm{A}$ 에서 본 유리섬유 배향은 리브를 따 라 올라가는 방향으로 일어나고 있고, B에서 본 배향은 리브 길이의 끝 부분이기 때문에 중앙 리브에서는 리브를 따라 올

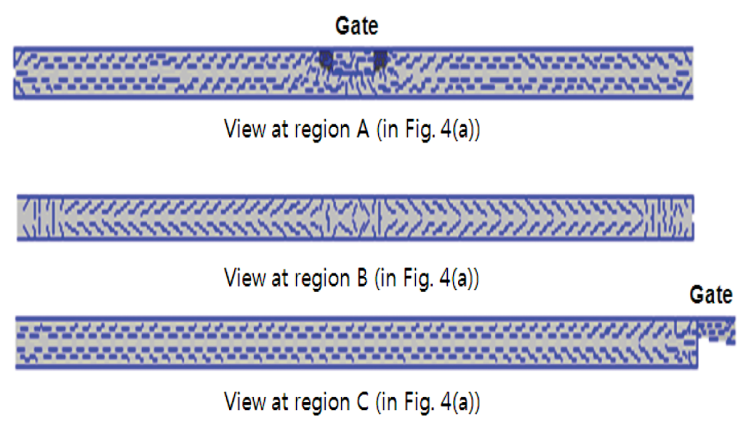

(a) Specimen 1

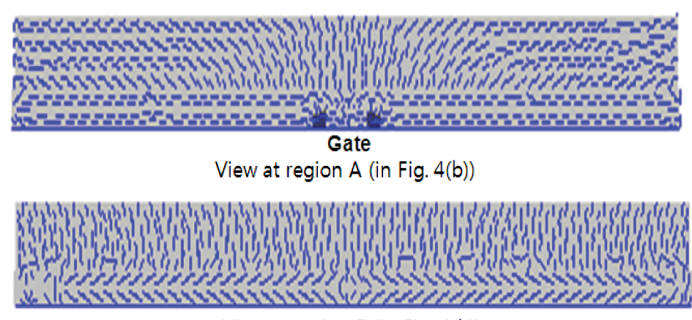

View at region $B$ (in Fig. $4(b)$ )

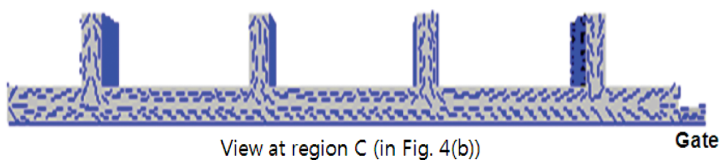

(b) Specimen 2
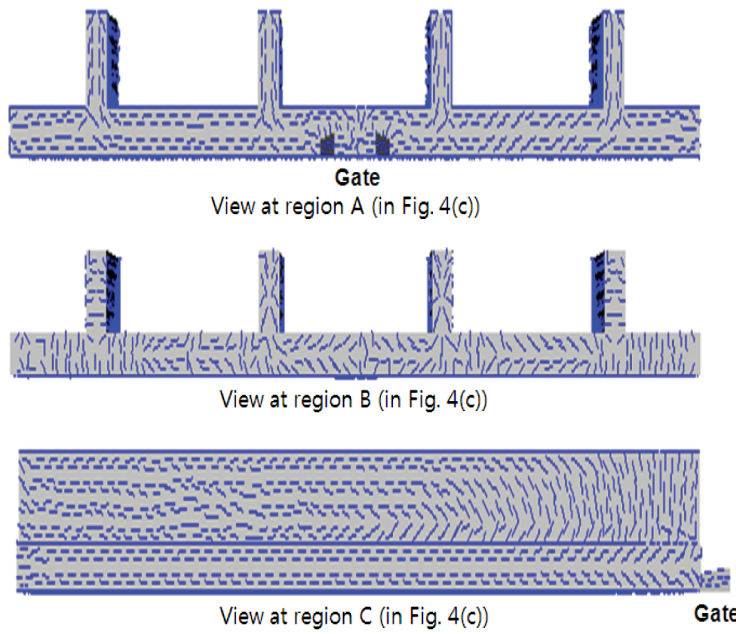

(c) Specimen 3

Figure 6. Distribution of fiber orientations in the specimens for glass fiber reinforced PC.

라가는 배향이 나타났고, 양 쪽 끝의 두 리브에서는 리브 두 께 방향으로 배향이 나타났다. 시편 3 의 C에서 본 유리섬유 배향은 게이트 부분에서는 리브 위쪽으로 일어났고 이 배향 이 리브 길이를 따라가면서 리브 길이 방향으로 배향됨을 볼 수 있다. 이상에서와 같이 성형품의 설계, 즉 리브의 설계에 
따라 흐름방향의 차이가 생기고 따라서 유리섬유 배향도 달 라져 휨의 크기에도 변화가 있을 것으로 예측된다.

시편의 형상 디자인에 따른 휨의 금형온도에 대한 영향. Figure 7은 유리섬유로 보강된 PC에서 금형온도에 따른 휨

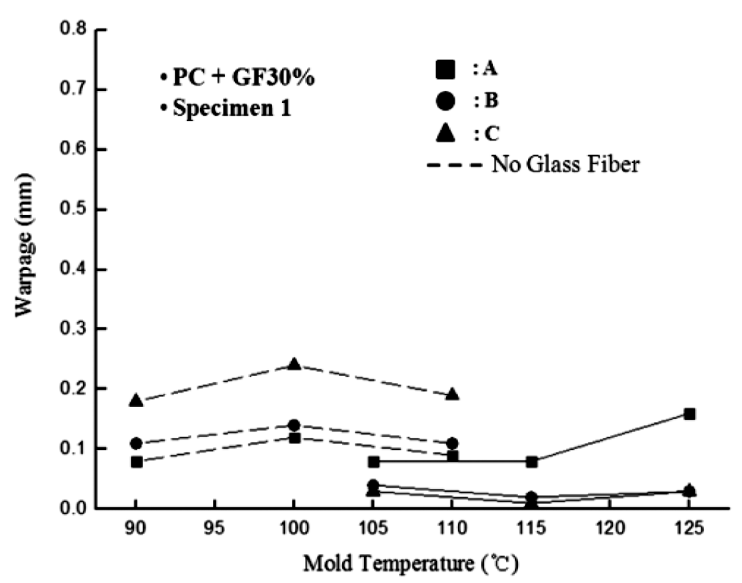

(a)Specimen 1

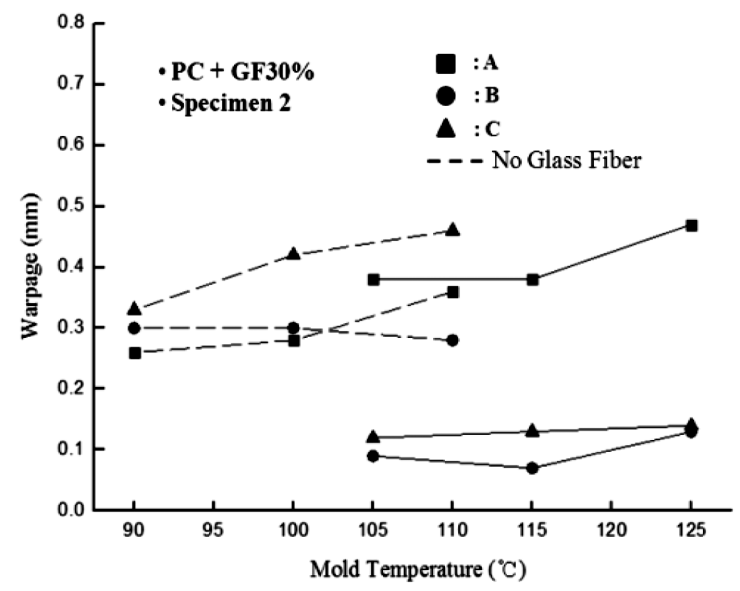

(b) Specimen 2

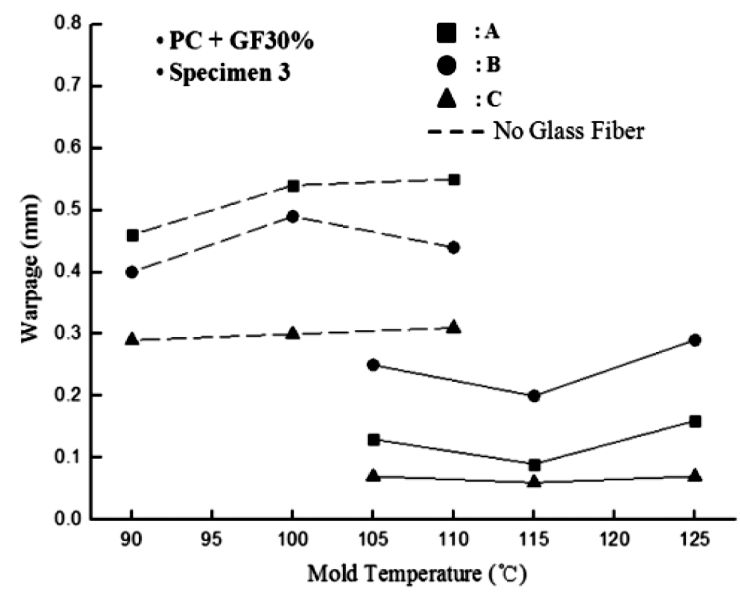

(c) Specimen 3

Figure 7. Warpages of the PC specimens as a function of mold temperature.
을 보여주고 있다. 그림에서 점선으로 나타난 선은 유리섬 유가 포함되지 않은 $\mathrm{PC}$ 의 휨을 참고로 보여 준 것이다. ${ }^{12}$ 유리섬유 보강에 따라 모든 시편에서 휨이 현저하게 줄어 듦을 볼 수 있고 휨의 경향도 다소 다르게 나타남을 볼 수 있다. ${ }^{12}$ 성형 시 금형온도가 높아짐에 따라 모든 시편에서 휨이 다소 증가함을 볼 수 있다. 시편 1 의 경우를 보면 게 이트 부분, $\mathrm{A}$ 에서 측정된 휨이 가장 컸고, 그 다음이 게이 트 반대쪽 $\mathrm{B}$ 이고, 그리고 흐름방향쪽 $\mathrm{C}$ 이다. 게이트 반대 쪽과 흐름방항쪽의 휨은 크게 차이가 없어 보인다. 사출성 형에서 일반적인 성형수축 양상을 보면 흐름방향보다 흐름 의 직각방향으로 수축이 크다. ${ }^{3,4}$ 따라서 수축이 크게 나타 나는 방향인 흐름의 직각방향 $\mathrm{A}$ 와 $\mathrm{B}$ 에서 휨이 크게 나타 났다고 판단된다. 게이트쪽의 휨이 큰 것은 사출성형 시 게이트에 가까운 부분이 압력을 크게 받게 되고 따라서 잔 류응력도 크게 남게 되며 이의 이완에 따라 변형이 커져서 나타난 것으로 판단된다. 리브가 흐름의 직각방향으로 놓 여있는 시편 2 에서의 휨의 경향을 보면 역시 $\mathrm{A}$ 부분의 휨 이 가장 컸고, 게이트 반대쪽인 $\mathrm{B}$ 부분에서 휨이 가장 작았 다. 시편의 $\mathrm{A}$ 부분에서 휨이 크게 나타난 것은 역시 게이 트와 가까운 부분이어서 과도한 압력을 받아 나타난 것으 로 판단된다. $\mathrm{B}$ 부분이 가장 휨이 작은 이유는 리브가 휨 방향으로 놓여있어 리브에 의한 강성 때문인 것으로 보인 다. 물론 $\mathrm{A}$ 부분도 리브에 의한 강성이 작용되긴 하지만 큰 압력을 받아 휨이 크게 나타났다고 판단된다. 그러나 시편 3 의 결과를 보면 $\mathrm{B}$ 에서 휨이 가장 컸고, $\mathrm{A}$ 와 $\mathrm{C}$ 가 그 다음이다. 시편 3은 리브가 흐름방향으로 놓여 있어서 흐름방향으로 리브의 강성이 작용되어 $\mathrm{C}$ 부분의 휨이 가장 작게 나타난 것으로 보인다. 흐름의 직각 방향으로의 강성 이 전혀 작용되지 않기 때문에 $\mathrm{A}$ 와 $\mathrm{B}$ 에서 휨이 크게 나타 나는데 게이트에서 먼 부분인 $\mathrm{B}$ 가 보압 효과를 적게 받게 되어 수축이 커지고 ${ }^{3,4}$ 따라서 $\mathrm{A}$ 보다 휨이 커진 것으로 판 단된다. 유리섬유로 보강된 Figure 8의 $\mathrm{ABS}$ 의 경우도 $\mathrm{PC}$ 와 휨의 경향이 같게 나타났다. 또한 휨의 양도 같은 비결 정성 수지여서 크게 차이가 없었다. 두 재료에서 가장 큰 휨은 시편 2의 $\mathrm{A}$ 방향에서 일어났고 전체적으로 휨이 가장 작은 것은 시편 1 이었으며, 시편 1 의 $\mathrm{A}, \mathrm{B}, \mathrm{C}$ 방향 순으 로 휨이 작았다. 일반적으로 사출제품에서 리브의 디자인 은 제품에 강성을 부여하기 위한 것이지만 휨이 크게 발생 되지 않는 형상에서는 리브로 인한 보강보다는 흐름의 이 방성과 제품 내 온도 편차를 증가시켜 오히려 휨을 더 유 발시키는 것을 볼 수 있었다. 그리고 리브는 수지의 흐름 방향으로 설계된 경우가 휨에 대한 저항이 큰 것으로 나타 났다. 이는 유리섬유가 리브방향으로 배향이 잘 되었기 때 문이다.

시편의 형상 디자인에 따른 휨의 보압에 대한 영향. Figure 9는 유리섬유로 보강된 $\mathrm{PC}$ 에서 시편 디자인에 따른 


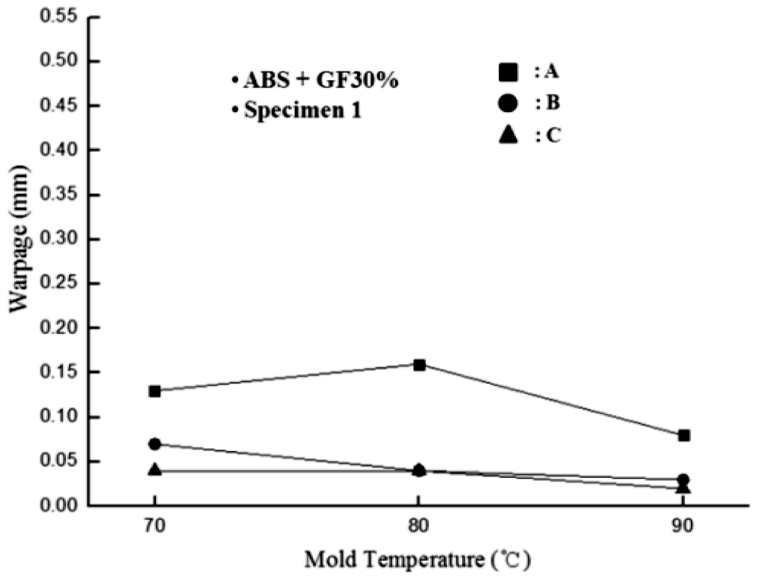

(a) Specimen 1

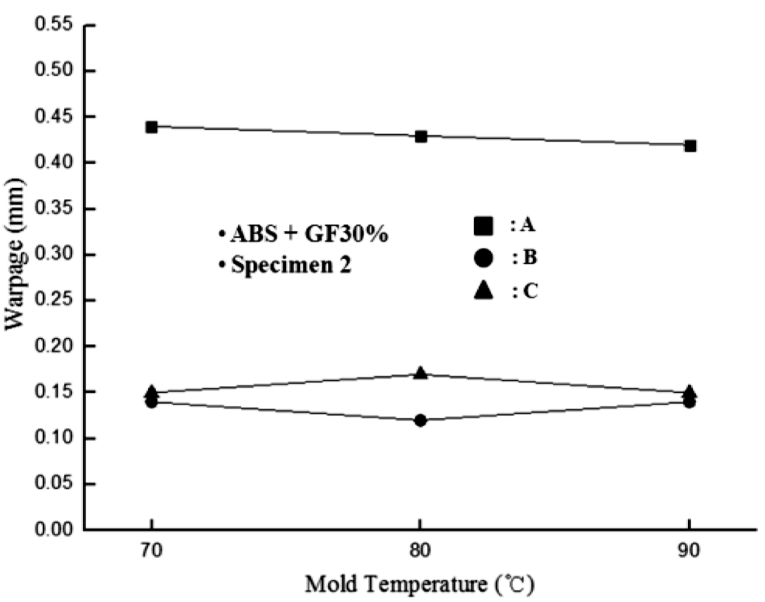

(b) Specimen 2

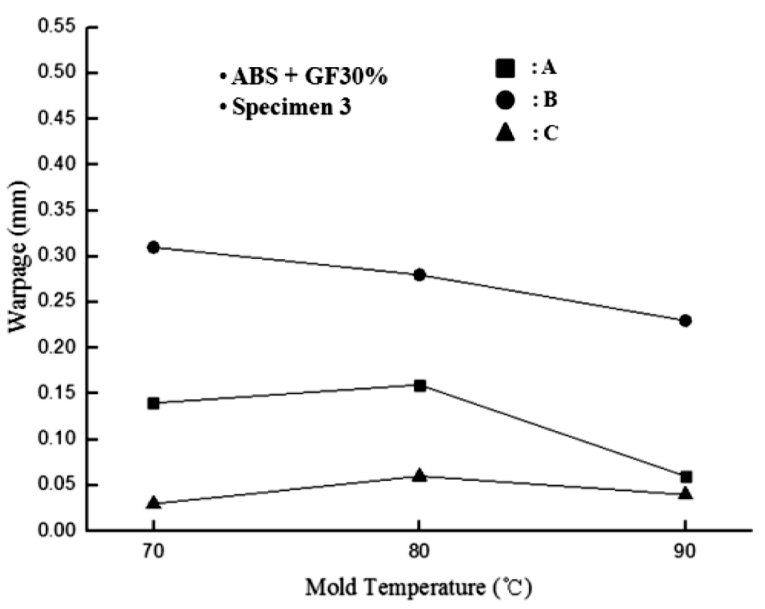

(c) Specimen 3

Figure 8. Warpages of the ABS specimens as a function of mold temperature.

휨의 양상을 보압에 따라서 나타내고 있다. 유리섬유로 보 강이 안된 $\mathrm{PC}$ 에서의 휨도 점선으로 나타내었다. ${ }^{12}$ 사출성형 에서 보압이 크면 성형수축이 작아지는 경향이 있으나 휨의

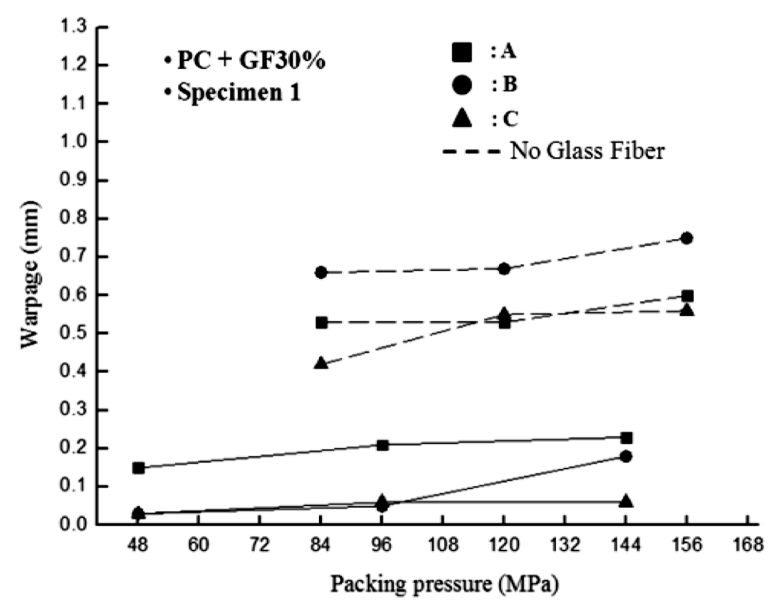

(a) Specimen 1

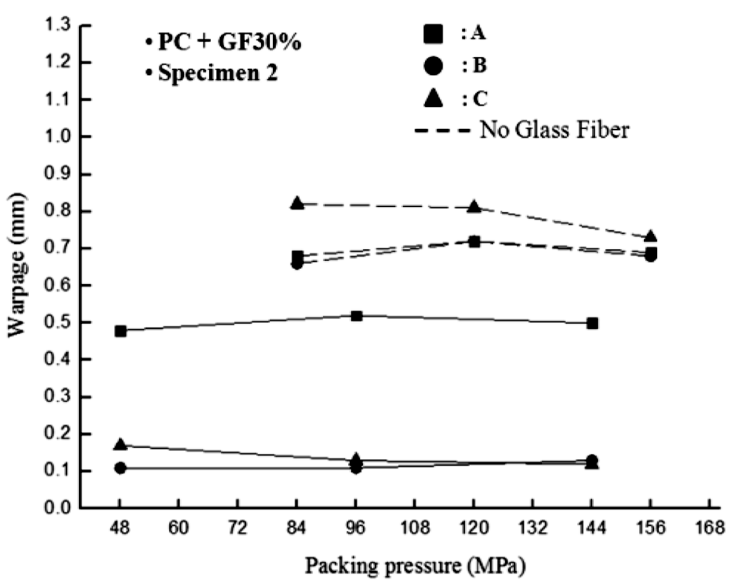

(b) Specimen 2

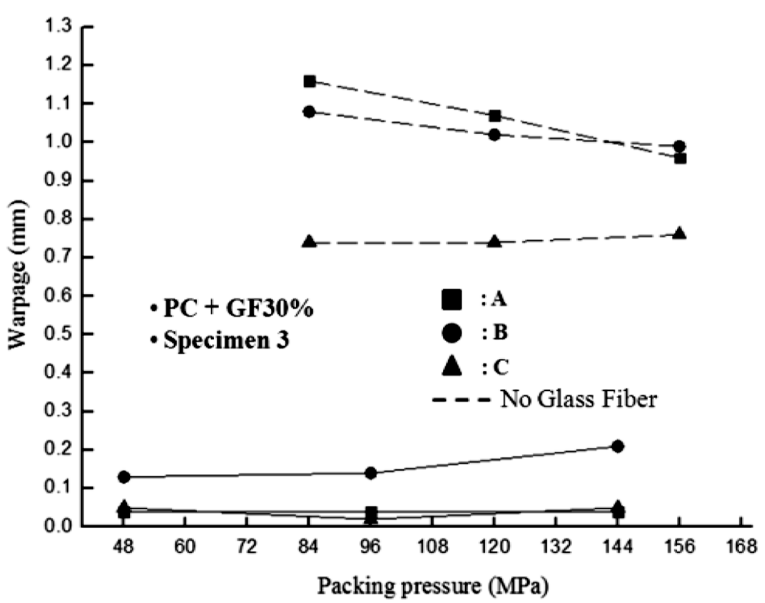

(c) Specimen 3

Figure 9. Warpages of the PC specimens as a function of packing pressure.

경우는 다소 다른 양상을 나타내었다. 보압이 커질수록 휨 이 감소하는 경향이 있지만 커지는 경향도 관찰되었다. 이 는 보압이 커질수록 제품의 성형수축은 줄일 수 있으나 위 


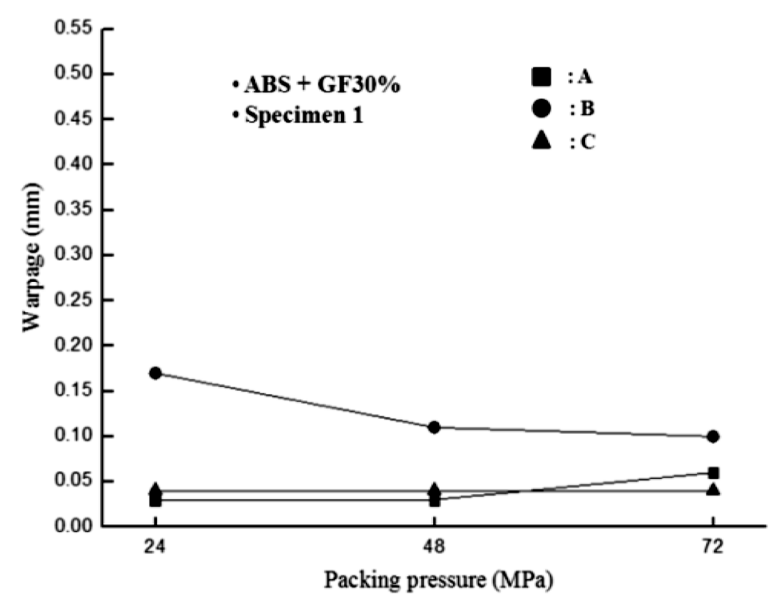

(a) Specimen 1

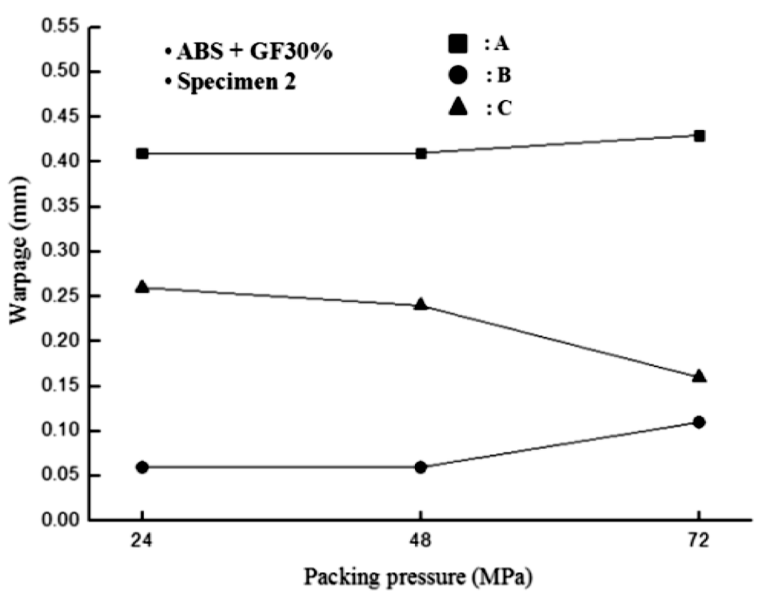

(b) Specimen 2

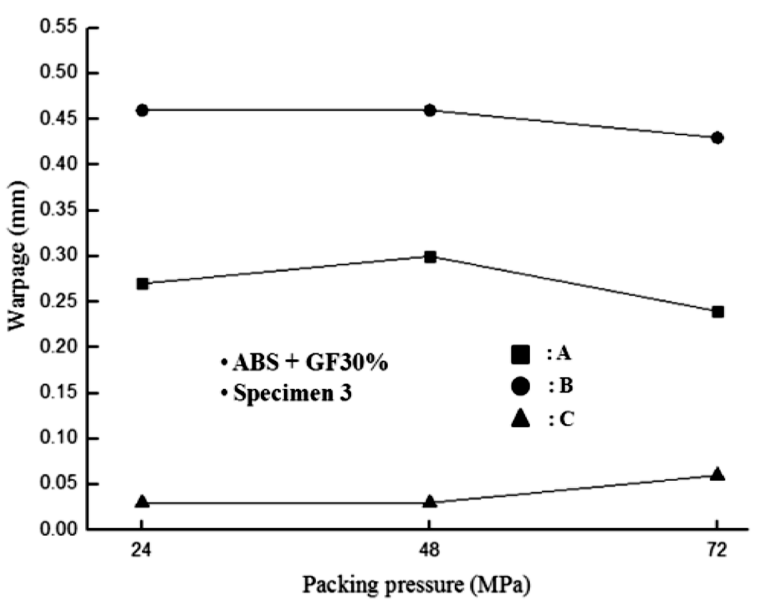

(c) Specimen 3

Figure 10. Warpages of the ABS specimens as a function of packing pressure.

치 별로 큰 잔류응력을 크게 남기게 되고 이것이 휨으로 나 타난 것으로 판단된다. 각 시편에서 위치 별 $(\mathrm{A}, \mathrm{B}, \mathrm{C})$ 로 나 타난 휨의 물리적인 상태는 수지의 유동선단과 유리섬유의
배향에서 설명한 바와 유사하게 나타났다. 단지 Figure 10(a) 의 $\mathrm{ABS}$ 시편1에서 $\mathrm{PC}$ 와 달리 $\mathrm{A}$ 부분의 휨이 낮게 나타난 것은 $\mathrm{ABS}$ 가 $\mathrm{PC}$ 보다 흐름성이 좋아(Figure 2) 성형 시 게이 트 부분인 $\mathrm{A}$ 부분에서 적절히 패킹이 잘 되었고, 과도한 압 력집중이 없어 잔류응력이 작아서 나타난 것으로 사료된다. 그리고 $\mathrm{B}$ 에서 가장 큰 휨을 보인 이유는 게이트에서 먼 부 분에서 보압의 영향이 작아 성형수축이 커져서 나타난 현상 이라 판단된다. 이 B부분의 휨은 Figure $10(\mathrm{a})$ 의 그래프에서 보듯 보압이 증가 할수록 현저하게 휨이 감소함을 알 수 있 다. $\mathrm{PC}$ 와 $\mathrm{ABS}$ 의 시편 2에서 $\mathrm{A}$ 부분이 가장 큰 휨을 보이는 데 이는 리브가 흐름에 직각으로 놓여 있어 흐름저항이 커 게이트 근처에서 큰 압력을 받았고, 이로 인해 잔류응력이 크게 되어 성형 후 큰 변형을 일으켰다고 판단된다. 그리고 리브의 보강 효과에 의해 $\mathrm{B}$ 부분의 휨이 가장 작게 나타났 다. 시편3의 경우 $\mathrm{B}$ 부분의 휨이 가장 큰데 이는 리브가 보 강되지 않는 방향으로 놓여 있고, 또한 게이트에서 멀어 압 력전달이 어렵기 때문에 수축이 커서 나타난 것으로 판단된 다. 휨은 금형온도나 보압과 같은 성형조건보다는 시편의 형상과 위치에 따라 크게 다름을 알 수 있다.

시편의 형상 디자인에 따른 휨의 수지온도에 대한 영향. Figure 11과 Figure 12는 $\mathrm{PC}$ 와 $\mathrm{ABS}$ 의 수지에서 사출성형 온도에 따른 각 시편별 휨을 보여주고 있다. 전체적으로 수 지온도가 증가할수록 휨이 증가하는 경향을 보였다. 사출성 형품의 성형수축에 대한 수지온도의 영향은 두 가지 면을 보이고 있다고 보고되고 있다. ${ }^{3,4}$ 수지온도가 높으면 점도가 낮아져 흐름성이 증가한다. 수지의 흐름성이 좋으면 사출성 형 시 압력 전달이 용이해지고 따라서 수지가 캐비티에 패 킹이 잘 된다. 결과적으로 수지온도가 높으면 패킹이 잘되 어 성형수축은 작아진다. 그러나 또 다른 측면은 사출 시 수지온도가 높으면 높은 온도에서 냉각온도까지 큰 온도 차 이 때문에 냉각 전후 체적의 변화가 커진다. 성형 시 체적 변화가 커지는 것은 성형수축이 커지는 것을 의미하기 때문 에 수지의 온도가 높은 것은 결국 큰 성형수축을 야기시킨 다. 이와 같이 사출 시 수지의 온도는 성형수축에 대해 두 가지 면을 가지고 있어서 사출성형공정의 상황에 따라, 즉 수지점도, 금형온도, 사출속도, 그리고 사출압력 등의 상황 에 따라 성형수축이 다소 커지기도 하고 다소 작아지기도 한다. Figure 11과 Figure 12에서는 수지온도 증가에 따라 휨이 다소 증가하고 있는데 이는 수지온도가 증가함에 따 라 성형수축이 다소 증가하는 방향으로 작용했기 때문인 것으로 판단된다. 시편 1,2 , 그리고 3 에서 휨의 물리적 양 상은 앞 절에서 살펴본 현상과 같다. 즉, 평판으로 설계된 시편 1 에서 휨이 가장 적었고, 리브가 흐름의 직각방향으 로 놓여 있는 설계에서 휨이 가장 컸다. 영역별 휨을 보면, 시편 2에서는 게이트 영역인 $\mathrm{A}$ 에서, 시편 3 에서는 게이트 반대쪽 영역인 $\mathrm{B}$ 에서 휨이 가장 컸다. 전체적으로 휨은 성 


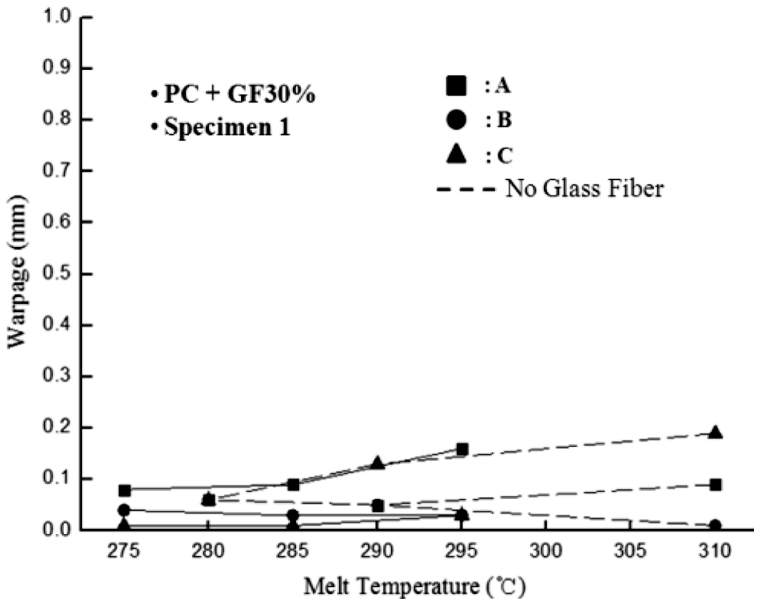

(a) Specimen 1

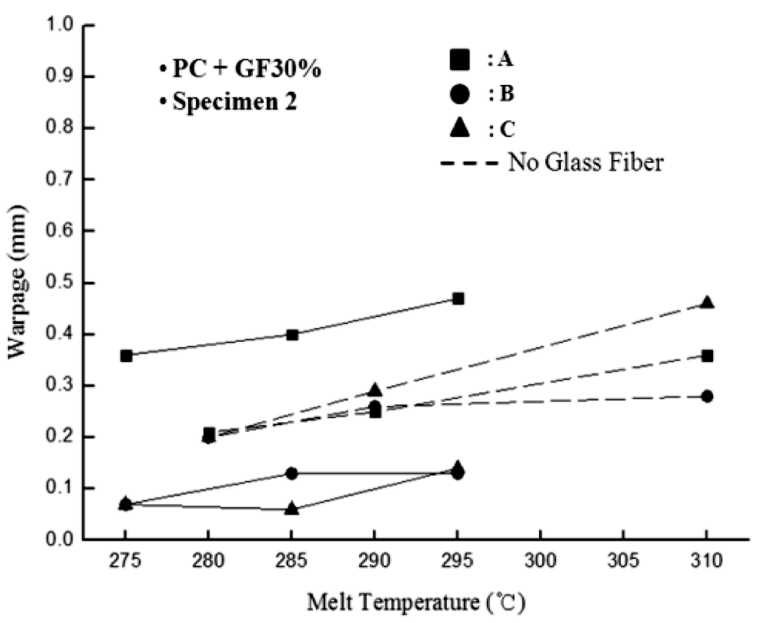

(b) Specimen 2

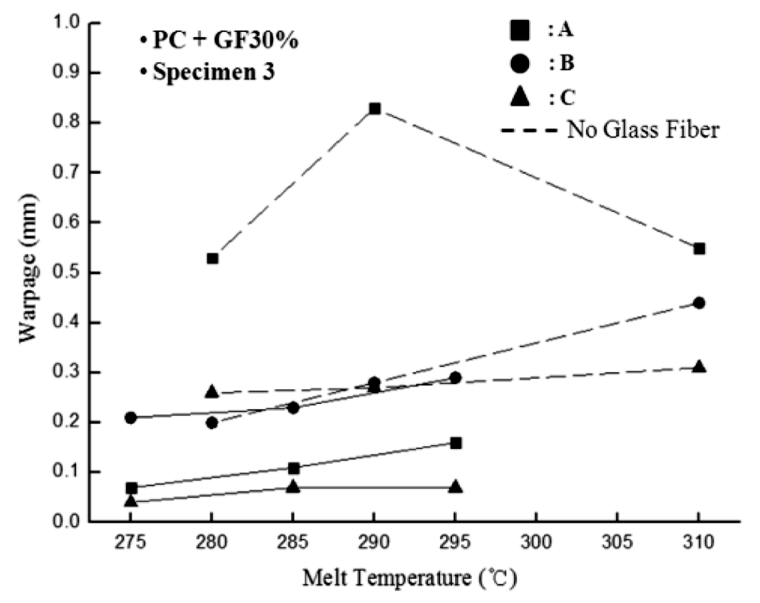

(c) Specimen 3

Figure 11. Warpages of the PC specimens as a function of melt temperature.

형조건보다는 시편의 설계와 위치에 따라 다르게 나타났다. 단지 성형조건에 따라 휨의 크기에 다소 차이가 있었다.

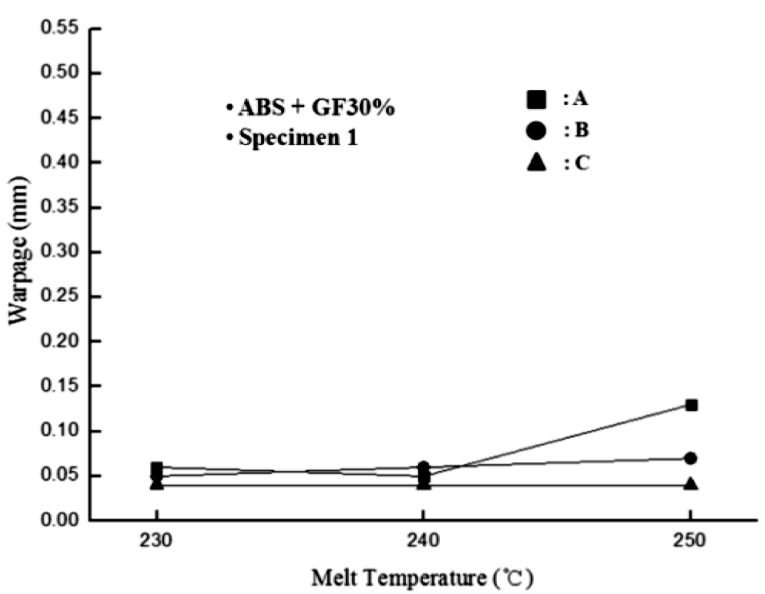

(a) Specimen 1

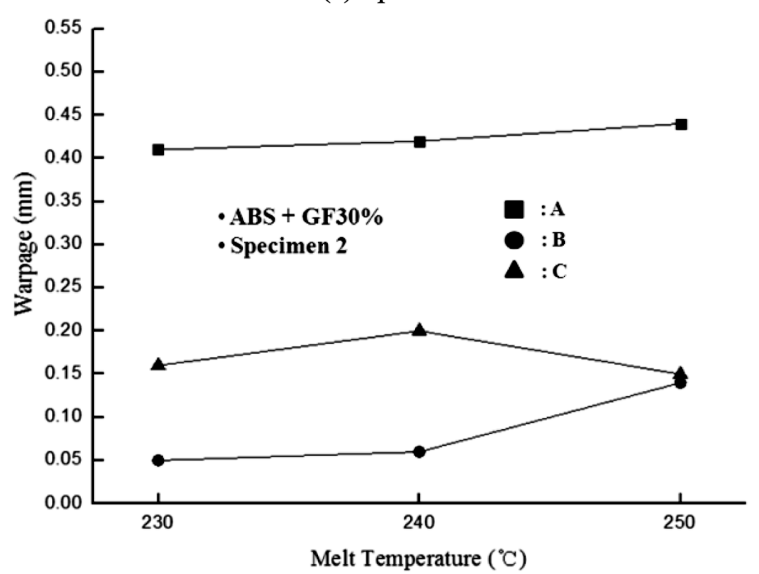

(b) Specimen 2

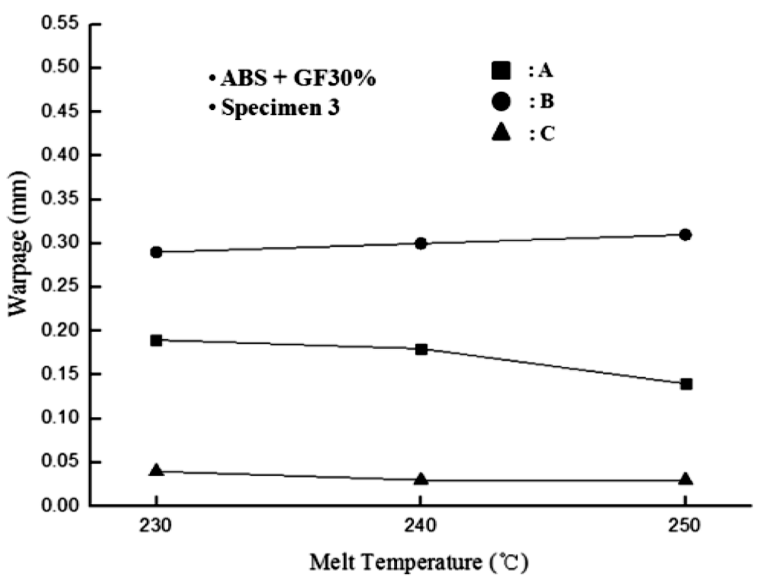

(c) Specimen 3

Figure 12. Warpages of the ABS specimens as a function of melt temperature.

\section{결 론}

본 연구는 유리섬유가 $30 \%$ 함유된 비결정성 수지인 $\mathrm{PC}$ 와 $\mathrm{ABS}$ 를 이용하여 시편의 형상 설계에 따라 보이는 휨을 조사 
하였으며 다음과 같은 결론을 얻었다.

(1) 유리섬유 $30 \%$ 로 보강된 비결정성 수지인 $\mathrm{PC}$ 와 $\mathrm{ABS}$ 의 휨은 서로 유사하였다. 리브가 없는 시편 1에서는 0.01 $0.22 \mathrm{~mm}$, 리브가 흐름의 직각으로 놓인 시편 2에서는 0.06 $0.50 \mathrm{~mm}$, 그리고 리브가 수지의 흐름방향으로 놓인 경우는 $0.02 \sim 0.46 \mathrm{~mm}$ 수준으로 휨이 나타났다. 이는 시편 길이 $100 \mathrm{~mm}$ 를 기준으로 각각 $0.01 \sim 0.22 \%, 0.06 \sim 0.50 \%$, 그리고 $0.02 \sim 0.46 \%$ 의 분포이다.

(2) 리브가 없는 편평한 시편 1 에서 휨의 양이 적었다. 그리 고 리브가 흐름방향으로 놓인 시편 3이 리브가 흐름방향의 직각으로 놓인 시편 2보다 휨이 작았다. 편평한 성형품이라면 변형을 방지하기 위한 리브의 설계가 필요없지만 휨을 방지 하기 위해 리브를 설계한다면 흐름방향으로 설계하는 것이 휨을 줄이는데 효과적임을 보였다. 금형설계 측면에서 본다면 성형품에 리브가 있다면 리브가 서있는 방향으로 수지의 흐 름이 가도록 게이트의 위치를 정해야 변형을 방지할 수 있다.

(3) 사출성형 조건은 다르게 설계된 시편에서 휨의 경향에 크게 영향을 주지 않았지만 대체로 수지의 온도가 높을수록 휨이 커지는 경향이 있었다. 휨을 줄이기 위해서는 적절한 보 압을 주어 수축보상을 해주고, 금형의 온도와 수지의 온도는 용융된 수지가 잘 흐를 수 있도록 적절한 온도를 유지해 주 어야 한다. 그러나 과도한 흐름, 즉 과도한 압력이 캐비티에 작용되는 조건은 성형품에 큰 잔류응력을 남겨 오히려 휨을 증가 시킬 수 있음을 확인할 수 있었다.

(4) 사출성형품의 휨에 영향을 미치는 요소는 제품의 형상 에 크게 의존함을 알 수 있었다. 또한 흐름 방향과 흐름의 직
각방향으로의 휨의 차이는 컸다. 따라서 제품의 형상설계와 게이트 위치 설정 즉, 금형설계가 휨을 줄이는데 가장 큰 요 소라 판단된다.

감사의 글: 본 과제(연구)는 지식경제부와 한국산업기술진 흥원의 전략기술인력양성사업으로 수행된 결과임.

\section{참 고 문 헌}

1. T. A. Osswald, L.-S. Turng, and P. J. Gramann, Injection Molding Handbook, Hanser, Munich, 2001.

2. M.-Y. Lyu and H.-Y. Kim, Polymer Science and Technology, 20, 157 (2009).

3. M.-Y. Lyu, J.-H. Mo, and W.-J. Jeong, Elastomers and Composites, 38, 295 (2003).

4. J. H. Mo and M.-Y. Lyu, Transact. Mater. Proc., 13, 515 (2004).

5. J. S. Hong, S. R. Park, and M.-Y. Lyu, Polymer(Korea), 35, 1 (2011).

6. K. Park, J.-H. Ahn, and C.-H. Yim, KSME, 27, 507 (2003).

7. S. J. Liao, D. Y. Chang, H. J. Chen, L. S. Tsou, J. R. Ho, H. T. Yau, and W. H. Hsieh, Polym. Eng. Sci., 44, 917 (2004).

8. H. Oktem, T. Erzurumlu, and I. Uzman, Mater. Design, 28, 1271 (2007).

9. M.-A. Kang and M.-Y. Lyu, Polymer(Korea), 32, 502 (2008).

10. Z. Lu and K. F. Zhang, Polym. Eng. Sci., 49, 1661 (2009).

11. P. Larpsuriyakul and H.-G. Fritz, Polym. Eng. Sci., 51, 411 (2011).

12. M. Lee, J. H. Kim, S. R. Park, and M.-Y. Lyu, Elastomers and Composites, 44, 373 (2009). 